\title{
Deep Sea Crabs of the Tasman Seamounts (Crustacea: Decapoda: Brachyura)
}

\author{
B. RICHER DE FORGES
}

ORSTOM,

BP A5, NOUMEA cedex, New Caledonia

\begin{abstract}
This study of a collection of deep sea crabs from the Tasman Sea contains eleven species, of which five are new: Halicarcinus lucasi, Macropodia trigonus, Leptomithrax depressus, Kimbla franklini, Pugettia tasmanensis.
\end{abstract}

RICHER DE FORGES, B., 1993. Deep sea crabs of the Tasman seamounts (Crustacea: Decapoda: Brachyura). Records of the Australian Museum 45(1): 11-24.

The collection of crabs in this study come from an Australian Museum cruise in May 1989 on board the RV Franklin, a CSIRO vessel. Part of the material from the cruise has already been the object of publications with the description of new material, Sphenocarcinus lowryi Richer de Forges, 1992, and a new genus (in press).

The zone explored is situated in the north-western Tasman Sea, the southern Coral Sea, and along the east coast of Australia. Most of the dredging, using an epibenthic sledge, took place in the upper bathyal zone, between 1600 and $120 \mathrm{~m}$. One of the objectives of this exploratory cruise was the sampling of the guyots aligned from north to south between $21^{\circ} \mathrm{S}$ (Chesterfield Islands) and $38^{\circ} \mathrm{S}$. These guyots came from a volcanic hot spot, and are evidence of the movement towards the north of the Indo-Australian plate (Van der Linden, 1969, 1970; Slater \& Goodwin, 1973); the oldest date from 28 M.Y. (Oligocene). Their small size and the huge oceanic distances which separate them make these guyots into oases of bathyal fauna in the middle of an immense desert of abyssal depths.
The small collection studied here contains eleven species, each represented by a small number of specimens. Five new species are described. The great originality of this fauna shows that the sampling of the bathyal zone is far from satisfactory.

All material is lodged in the Australian Museum, Sydney (AM) or the New Zealand Oceanographic Institute, Wellington (NZOI).

\section{Species List}

\section{Homolidae}

Latreillopsis aff. multispinosa Ihle, 1912

Hymenosomatidae

Halicarcinus lucasi n.sp.

Majidae

Achaeus curvirostris (A. Milne Edwards, 1873)

Achaeus sp.

Macropodia trigonus n.sp.

Leptomithrax tuberculatus Whitelegge, 1900 